\title{
Vegetative propagation and application of clonal forestry in Brazilian native tree species
}

\author{
Carlos André Stuepp ${ }^{(1)}$, Ivar Wendling ${ }^{(2)}$, Aloisio Xavier $^{(3)}$ and Katia Christina Zuffellato-Ribas ${ }^{(4)}$
}

\begin{abstract}
(1)Universidade Estadual de Ponta Grossa, Departamento de Fitotecnia, Campus de Uvaranas, Bloco F, Sala 08, Avenida Carlos Cavalcanti, no 4.748, Uvaranas, CEP 84030-900 Ponta Grossa, PR, Brazil. E-mail: castuepp@uepg.br (2)Embrapa Florestas, Estrada da Ribeira, Km 111, Caixa Postal 319, Guaraituba, CEP 83411-000 Colombo, PR, Brazil. E-mail: ivar.wendling@embrapa.br ${ }^{(3)}$ Universidade Federal de Viçosa, Avenida P.H. Rolfs, s/no, Campus Universitário, CEP 36571-000 Viçosa, MG, Brazil. E-mail: xavier@ufv.br (4)Universidade Federal do Paraná, Departamento de Botânica, Setor de Ciências Biológicas, Avenida Coronel Francisco H. dos Santos, no 100, Caixa Postal 19.031, CEP 81531-980 Curitiba, PR, Brazil. E-mail: kazu@ufpr.br
\end{abstract}

\begin{abstract}
Understanding the mechanisms involved in tree species maturation, related mainly to ontogenetic age effects, has contributed significantly to the vegetative propagation process of Brazilian native tree species, with consequent application of clonal forestry. A number of methodologies has been developed to rescue and vegetatively propagate these species for silvicultural and environmental restoration purposes. However, the types and purposes of propagation, as well as the choice of suitable processes and propagules considering the intended objectives, still need to be better aligned. In addition, there is an evident knowledge gap and great potential regarding the use of native tree species in Brazilian clonal forestry, indicating the need of a greater interaction between studies on the vegetative propagation and vigor of these materials in the field. Therefore, this review aims to help understand the different types of techniques used and their application on the vegetative propagation and clonal forestry of Brazilian native tree species, besides proposing a schematic sequence of the stages involved in these processes for productive and environmental purposes.
\end{abstract}

Index terms: air-layering technique, cuttings, grafting, mini-cuttings technique, rejuvenation of forest tree species, vegetative rescue.

\section{Propagação vegetativa e aplicação da silvicultura clonal em espécies arbóreas nativas do Brasil}

\begin{abstract}
Resumo - A compreensão dos mecanismos envolvidos na maturação em espécies arbóreas, relacionados principalmente aos efeitos da idade ontogenética, tem contribuído de forma significativa ao processo de propagação vegetativa de espécies nativas, com consequente aplicação da silvicultura clonal. Uma série de metodologias tem sido desenvolvida para o resgate e a propagação vegetativa dessas espécies para fins silviculturais e de restauração ambiental. No entanto, ainda precisam ser mais bem alinhados os tipos e os propósitos da propagação, bem como a escolha dos processos e dos propágulos adequados tendo em vista os objetivos almejados. Além disso, há uma lacuna evidente de conhecimento e um grande potencial referente ao uso de espécies arbóreas nativas na silvicultura clonal brasileira, o que indica a necessidade de maior afinidade entre estudos de propagação vegetativa e do vigor desses materiais em campo. Assim, esta revisão tem por objetivo auxiliar no entendimento das diferentes técnicas e de suas aplicações na propagação vegetativa e na silvicultura clonal de espécies arbóreas nativas, bem como propor uma sequência esquemática das etapas envolvidas nesses processos para fins produtivos e ambientais.
\end{abstract}

Termos para indexação: alporquia, estaquia, enxertia, miniestaquia, rejuvenescimento de espécies florestais, resgate vegetativo.

\section{Introduction}

Much has been studied and discussed regarding species well recognized by Brazilian silviculture, mainly of the genera Eucalyptus and Pinus (Xavier et al., 2013). However, there are few researches on species native to the country and most of them do not go beyond the experimental stages.
In general, in forestry, native species can be used for the following purposes: commercial, for the production of timber and non-timber products; and environmental, including the restoration of forest ecosystems. For environmental purposes, specifically in clonal forestry, certain requirements should be met for a consistent use of the tree species, particularly

Pesq. agropec. bras., Brasília, v.53, n.9, p.985-1002, Sept. 2018 DOI: 10.1590/S0100-204X2018000900002 
an adequate genetic variability in clonal plantations (Carpanezzi \& Carpanezzi, 2006).

The lack of knowledge about the potential use, production technologies, and management of native tree species, whether for productive or environmental purposes, has been one of the greatest limiting factors to the application of propagation techniques in clonal forestry. This not only includes the propagation process, but also the proper selection of genetic material with sufficient quality and levels of genetic variability for the intended purposes.

For the promising use of native species in clonal forestry, there must be a full understanding of the stages that precede it, including vegetative rescue and the establishment of the basic standards to achieve the desired objectives. Studies on the application of vegetative rescue techniques to native tree species have shown important aspects for the success of clonal forestry, highlighting the effects of ontogenetic age, which may vary according to the adopted technique (Xavier et al., 2013). In the case of vegetative propagation by cuttings, the use of crown shoots of an advanced ontogenetic age reduced the percentages of propagule rooting (Ciriello \& Mori, 2015). However, satisfactory rooting indexes were obtained with the use of spontaneous or induced basal sprouts, resulting in a greater efficiency in the vegetative rescue of the species (Rickli et al., 2015).

The use of juvenile shoots in the vegetative propagation of native tree species has been recommended since the middle of the last century, when there was already knowledge of the effects of using basal shoots and canopy (Baptist, 1939). When mature propagules are not required, vegetative propagation is easily obtained with juvenile propagules, whether young plants or even basal epicormic sprouts (Wendling et al., 2014a; Dias et al., 2015b).

If applied consistently, vegetative propagation can be an excellent alternative for the production of plants for environmental purposes, solving the problem of low genetic variability by using a larger number of mother trees to obtain the initial propagules (Carpanezzi \& Carpanezzi, 2006). This allows to vegetatively propagate species that show limitations in seminal propagation, such as seed unavailability and high acquisition cost, low germination percentages, and a long period of time for seedling production in programs aiming the restoration of degraded ecosystems (Oliveira \& Ribeiro, 2013).

A number of methodologies has been developed for the rescue and vegetative propagation of native tree species for silvicultural and environmental restoration purposes. However, there has been confusion regarding the different types and purposes of propagation, as well as the choice of suitable processes and propagules considering the intended objectives. In addition, there is an evident knowledge gap and great potential regarding the use of these species in Brazilian clonal forestry, indicating the need of a greater interaction between studies on the vegetative propagation and vigor of these materials in the field. Therefore, this review aims to help understand the different types of techniques and their application in vegetative propagation and clonal forestry of Brazilian native tree species, with a detailed bibliographical survey regarding the state of the art related to these themes, as well as discussions of the knowledge gaps that need to be filled.

\section{Induction of juvenile sprouts in Brazilian native tree species}

The rejuvenation and/or reinvigoration of adult plants is a frequently adopted technique in the vegetative rescue of superior genotypes. It has been regularly used in native tree species, aiming the induction (production) of juvenile propagules, which are more suitable for vegetative propagation, especially for adventitious rooting (Dias et al., 2015b; Rickli et al., 2015), often eliminating the need for plant regulator application (Rickli et al., 2015; Stuepp et al., 2015).

Rejuvenation and/or reinvigoration in native tree species have been achieved primarily by the coppicing, girdling, semi-girdling, and drastic pruning techniques (Xavier et al., 2013). Each technique should be evaluated individually for the species/clone to be rescued and applied with the greatest efficiency possible in order to cause less damage to the mother plant, ensuring its integrity.

The use of coppicing has been efficient in the induction of epicormic sprouts in several native tree species (Santin et al., 2008; Dias et al., 2015b). However, the productivity and vigor of these stumps was not assessed in a significant number of studies, and the technique was often performed only for 
epicormic-sprout-producing purposes, where the focus is only propagation by cuttings (Stuepp et al., 2015). In other cases, coppicing was used for adult plant reinvigoration or even as a regrowth management technique (Sampaio et al., 2005).

Regardless of its purposes, coppicing has an excellent potential. In Hevea brasiliensis (Willd. ex A.Juss.) Müll.Arg. and Ilex paraguariensis A.St.-Hil., it has been effective when used to replace canopies through grafting (Pinheiro et al., 1988; Wendling et al., 2009b). Specifically for I. paraguariensis, in order to improve the efficiency of the cultivation process, the technique has been recommended to recover degraded plantations (Santin et al., 2008) and to produce vegetative propagules (Stuepp et al., 2016a); in both cases, a high efficiency was observed in the induction of epicormic sprouts (Table 1). The efficacy of coppicing to induce epicormic sprouts has also been shown for several other species. For Araucaria angustifolia (Bertol.) Kuntze, the technique has been applied exclusively for vegetative propagation purposes, following the principles of woody plant maturation for logging (Wendling et al., 2014a; Wendling \& Brondani, 2015).

Total or partial girdling, similarly to coppicing, can be performed at different heights, always taking into account the increased maturity of sprouts from the trunk base towards the apex (Wendling et al., 2014b) (Figure 1). The two techniques cause less damage to the mother plant, which often shows low vigor, usually due to old age, genetic characteristics, or even phytosanitary conditions, when coppicing becomes impractical (Dias et al., 2015b; Stuepp et al., 2015).

The results obtained until now regarding the use of the girdling technique have been promising. However, in comparison with coppicing, a lower sprout productivity was reported (Dias et al., 2015b; Stuepp et al., 2015, 2016a; Kratz et al., 2016). It should be noted, though, that, in the case of the vegetative rescue of high-genetic-value plants, both techniques are important because they interfere less on the mother plant, better guaranteeing its survival (Kratz et al., 2016).

The efficiency of total girdling regarding the emission of epicormic sprouts has been described for some native species (Table 2). However, a limiting factor is the difficulty of performing this technique without directly reaching the cambium (Kratz et al., 2016), besides the fact that it alone causes serious and permanent damage to the girdled plants. Despite this, the adequate application of girdling may promote partial or total healing of the wound, justifying its use in vegetative rescue as a way to guarantee the maintenance of live plants (Santin et al., 2008).

Partial girdling is used even less than total girdling. The reason is that the research works that employ this vegetative rescue technique are usually not very specific, use a large number of individuals, and show

Table 1. Application of the coppicing technique to induce juvenile sprouts in Brazilian native tree species.

\begin{tabular}{|c|c|c|c|c|c|c|}
\hline $\operatorname{Age}^{(1)}$ & $\operatorname{Height}^{(2)}(\mathrm{cm})$ & Period & Efficiency $^{(3)}(\%)$ & Purpose $^{(4)}$ & Species & Reference \\
\hline $3-5$ & 20 & October & 90.0 & Cuttings & Anadenanthera macrocarpa & Dias et al. (2015b) \\
\hline 19 & 100 & - & - & Regrowth management & Aniba rosaeodora & Sampaio et al. (2005) \\
\hline 26 & 20 & July & 60.0 & Cuttings & Araucaria angustifolia & $\begin{array}{l}\text { Wendling et al. (2009a) and } \\
\text { Wendling \& Brondani (2015) }\end{array}$ \\
\hline 14 & 30 & October & 100.0 & Cuttings & Calophyllum brasiliense & Kratz et al. (2016) \\
\hline Adult $^{(5)}$ & 50 and 100 & April & - & Cuttings & Campomanesia xanthocarpa & Teleginski (2016) \\
\hline 7 & - & - & - & Cuttings & Dalbergia nigra & Fonseca et al. (1991) \\
\hline 6 & $15,30,45$, and 60 & December & - & Cuttings & Eremanthus erythropappus & Melo et al. (2012) \\
\hline- & $15-20$ & November & 50.0 & Cuttings & Eremanthus erythropappus & Rezende (2007) \\
\hline 4.6 & 10 and 30 & August & - & Cuttings & Eugenia uniflora & Peña Peña (2014) \\
\hline 17 & 60 & Winter & - & Cuttings & Ilex paraguariensis & Bitencourt et al. (2009) \\
\hline 3 & - & June & - & Layering & Feijoa sellowiana & Mielke et al. (1994) \\
\hline 17 and 80 & 15,30 , and 60 & $\begin{array}{l}\text { Winter and } \\
\text { summer }\end{array}$ & 97.2 & Cuttings & Ilex paraguariensis & $\begin{array}{l}\text { Stuepp et al. }(2015,2016 \mathrm{a}, \\
\text { 2017b) }\end{array}$ \\
\hline 25 & - & Winter & - & Regrowth management & Tabebuia cassinoides & Bernhardt (2003) \\
\hline- & 150 & March & - & Cuttings & Vochysia bifalcata & Rickli et al. (2015) \\
\hline
\end{tabular}

${ }^{(1)}$ Estimated age of mother tree in years. ${ }^{(2)}$ Height of coppicing. ${ }^{(3)}$ Percentage of plants with emission of sprouts after the application of coppicing. ${ }^{(4)}$ Reason why the technique was applied. ${ }^{(5)}$ Plant at the reproductive stage. -, no information available. 

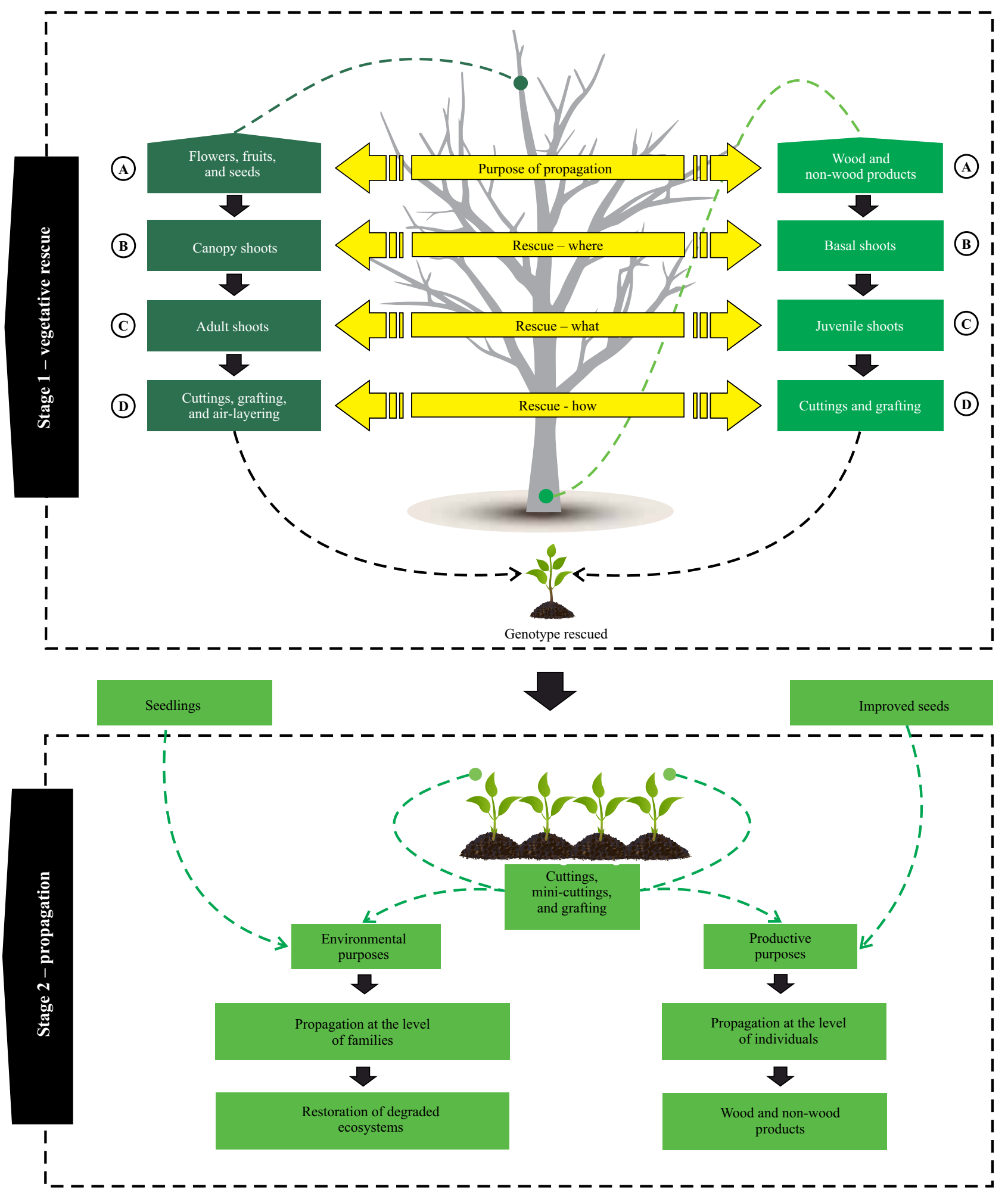

Figure 1. Schematic sequence of the vegetative rescue of adult plants and mass propagation of native species: A, final objectives of vegetative rescue; $\mathrm{B}$, origin of propagules; $\mathrm{C}$, type of propagules; and $\mathrm{D}$, recommended technique. 
little or no genetic improvement to the mother trees. Therefore, more invasive and efficient techniques are commonly adopted, such as coppicing or total girdling. Although it is less used in native tree species, partial girdling can be an excellent alternative when working with unique genetic materials, where the loss of a mother tree may result in irreparable genetic losses (Kratz et al., 2016). The efficiency in epicormic sprout emission using this technique in native tree species is lower than that of total girdling and coppicing (Tables 1 and 2), in the following order: coppicing $>$ total girdling $>$ partial girdling.

Other techniques for epicormic sprout induction in native tree species were evaluated, standing out pruning of canopy branches, sprouting of detached branches in a greenhouse, and stem span (Wendling et al., 2009a, 2013; Rickli et al., 2015). For A. angustifolia, pruning was carried out on the orthotropic tip (apex) of adult plants for grafting and early seed production (Wendling et al., 2016b), as well as on plagiotropic branches (lateral branches) for cuttings (Wendling et al., 2009a). The branches of this same species (Wendling et al., 2009a) and of I. paraguariensis (Wendling et al., 2013) and Campomanesia xanthocarpa O.Berg (Teleginski, 2016) were detached in a greenhouse, aiming vegetative propagation by cuttings.

Finally, stem span, a technique quite dependent on the diameter and resistance of the stem and that is generally applied to younger plants, was reported for C. xanthocarpa (Teleginski, 2016), Eremanthus erythropappus (DC.) MacLeish (Rezende, 2007), and Vochysia bifalcata Warm. (Rickli et al., 2015) (Table 2).

Table 2. Application of total and partial girdling, pruning of canopy branches, sprouting of detached branches, and stem span in the induction of juvenile sprouts in Brazilian native tree species.

\begin{tabular}{|c|c|c|c|c|c|c|}
\hline $\operatorname{Age}^{(1)}$ & $\operatorname{Height}^{(2)}(\mathrm{cm})$ & Period & $\begin{array}{c}\text { Efficiency }^{(3)} \\
(\%)\end{array}$ & Purpose $^{(4)}$ & Species & Reference \\
\hline & \multicolumn{6}{|c|}{ Total girdling } \\
\hline 3 and 5 & 20 & Spring & 90.0 & Cuttings & Anadenanthera macrocarpa & Dias et al. (2015b) \\
\hline 14 & 30 & Spring & 90.0 & Cuttings & Calophyllum brasiliense & Kratz et al. (2016) \\
\hline- & 50 and 100 & April & - & Cuttings & Campomanesia xanthocarpa & Teleginski (2016) \\
\hline- & $15-20$ & Spring & 0.0 & Cuttings & Eremanthus erythropappus & Rezende (2007) \\
\hline 30 and 50 & 20 & Spring & 83.3 & Invigoration & Ilex paraguariensis & Santin et al. (2008) \\
\hline \multirow[t]{2}{*}{17 and 80} & 30 & Winter and summer & 95.8 & Cuttings & Ilex paraguariensis & Stuepp et al. $(2015,2016 a, 2017 a)$ \\
\hline & \multicolumn{6}{|c|}{ Partial girdling } \\
\hline \multirow[t]{2}{*}{14} & 30 & Spring & 30.0 & Cuttings & Calophyllum brasiliense & Kratz et al. (2016) \\
\hline & \multicolumn{6}{|c|}{ Pruning of canopy branches } \\
\hline 26 & Apex removal & Winer & 50.0 & Cuttings & Araucaria angustifolia & Wendling et al. (2009a) \\
\hline 20 & $20-50^{(5)}$ & Spring & - & Cuttings & Araucaria angustifolia & Wendling et al. (2009a) \\
\hline \multirow[t]{2}{*}{-} & - & April & - & Cuttings & Campomanesia xanthocarpa & Teleginski (2016) \\
\hline & \multicolumn{6}{|c|}{ Sprouting of detached branches kept in a greenhouse } \\
\hline 20 & 50 & Spring & 2.1 & Cuttings & Araucaria angustifolia & Wendling et al. (2009a) \\
\hline 19 & 60 & Spring & - & Cuttings & Ilex paraguariensis & Wendling et al. (2013) \\
\hline \multirow[t]{2}{*}{-} & 100 & April & - & Cuttings & Campomanesia xanthocarpa & Teleginski (2016) \\
\hline & \multicolumn{6}{|c|}{ Stem span } \\
\hline- & - & April & - & Cuttings & Campomanesia xanthocarpa & Teleginski (2016) \\
\hline - & - & Spring & 50.0 & Cuttings & Eremanthus erythropappus & Rezende (2007) \\
\hline - & - & Autumn & - & Cuttings & Vochysia bifalcata & Rickli et al. (2015) \\
\hline
\end{tabular}

${ }^{(1)}$ Estimated age of mother tree in years. ${ }^{(2)}$ Height of technique application. ${ }^{(3)}$ Percentage of plants with emission of sprouts after technique application. ${ }^{(4)}$ Reason why the technique was applied. ${ }^{(5)}$ Length in relation to the insertion of the plagiotropic branches in the orthotropic trunk. -, no information available. 
In summary, information on coppicing and total and partial girdling in native tree species is still scarce, with gaps regarding vegetative vigor and the ability to produce epicormic shoots, either for vegetative rescue or for the reinvigoration of senescent plants.

\section{Vegetative rescue in Brazilian native tree species by canopy sprouts and basal epicormic shoots}

Vegetative rescue in native tree species can be performed by canopy sprouts and basal epicormics shoots. Each technique has its applications, advantages, and disadvantages, defined mainly according to the species and intended results.

Vegetative rescue by canopy sprouts has been carried out mostly by cuttings, layering, and grafting. Its application in clonal forestry has been linked to the maturation of propagules, and it is recommended for the production of flowers, fruits, and seeds (Figure 1). Its main advantage is maintaining maturity characteristics associated with the propagules or other parts of adult plants, while its disadvantages are observed especially when associated with the cuttings technique, limiting or inhibiting rhizogenesis in most cases. In spite of this, this was the first method applied to evaluate rooting capacity at an experimental level in native species, due to the immediate availability of shoots, without damaging the parent plant.

The experiments with canopy sprouts performed to date showed that the rooting capacity of this type of propagule varies according to species, age of the parent plant, climatic conditions at the time of application, and the effect of the use of plant regulators (Martins et al., 2015). Over the last ten years, most obtained results were inefficient for rooting of canopy shoots; however, based on the proposed goal for the vegetative rescue of adult plants, there is no need to achieve high rooting percentages for the technique to be considered viable. This is explained by the fact that, even in reduced percentages, rooting allows the subsequent multiplication of genetic material through more efficient methodologies such as cuttings (clonal hedge), mini-cuttings (mini-clonal hedge), or even grafting. It should be highlighted though that, based on the hypothesis that a greater maturity of canopy propagules leads to better sprouting (Wendling et al., 2014b), the use of the cuttings technique is not recommended for the vegetative propagation of crown shoots (Figure 1).

There are species, however, with good aptitude for adventitious rooting of canopy shoots, standing out among them Maytenus muelleri Schwacke from plantations managed with up to $62.5 \%$ of cuttings rooted in summer (Lima et al., 2011). In spite of the good results for some tree species, the morphophysiological characteristics of this type of sprouting, in general, do not favor rooting and root vigor of the propagules. In experiments, its use tends to be evaluated jointly with methodologies for the induction of juvenile shoots that have greater aptitude for adventitious root formation (Bitencourt et al., 2009; Stuepp et al., 2016a), facilitating the vegetative rescue of native species.

Layering is not commonly used in native tree species, mainly because it is a high-cost method with low operational efficiency. However, it has a high potential for the rescue of superior genetic material, since it is only performed on the branches of the mother tree, causing little or no damage. As with the cuttings technique, the use of layering in woody species should take into account the maturity of the plant or of each part to be rescued, considering that the older the tree is, the lower is its capacity for adventitious root emission (Wendling et al., 2014b). The recommendation of layering is directly related to the productive purposes of the species to which it is being applied, since this technique uses the crown shoot, which shows characteristics related to maturity, considered essential for the production of flowers, fruits, and seeds (Figure 1). As shown in Table 3, layering has been successfully applied in some native tree species.

Similar to layering, grafting is not commonly used in the vegetative rescue of native forest tree species, but of fruit trees (Franzon et al., 2010). The efficiency of the technique depends on the compatibility between rootstock and graft (Han et al., 2013), the application environment (field or nursery) (Wendling et al., 2016a), and the physiological quality of the used propagules (Martínez-Ballesta et al., 2010), among others.

Grafting has been widely adopted in commercial horticulture and can provide great benefits for the establishment of seed orchards, with the potential use of resistant or tolerant rootstocks and more productive grafts, as proposed for A. angustifolia (Wendling, 2015; Wendling et al., 2016a). Another application of the technique is the rejuvenation of adult propagules 
by serial grafting on juvenile rootstocks (Wendling \& Xavier, 2001; Santin et al., 2015).

Grafting is a technique that tends to be used more as the genetic improvement of native tree species evolves, being applied during the formation of clonal orchards for improved seed production and controlled crosses, as already reported for Pinus spp. and Eucalyptus spp. (Rocha et al., 2002). Its application in native tree species depends on the purpose of the rescue, since, with this technique, except serial grafting, characteristics related to the maturity of the parent plant are carried on. In general, the application of grafting tends to be more adequate when the objective is producing flowers, fruits, and seeds (Figure 1). Grafting has been a reference in the rescue of adult I. paraguariensis trees, primarily for multiplying superior genetic material (Wendling et al., 2009b) and to obtain a certain degree of graft rejuvenation from adult propagules (Santin et al., 2015).

The first studies about rooting of basal epicormic shoots in native tree species were performed on $H$. brasiliensis with the use of sprouts accidentally stimulated at the base of the plants (Muzik \& Cruzado, 1956). More recently, several works have dealt with the rooting of propagules originating from this type of shoot in native tree species (Table 4), with the preponderant use of coppicing for the induction of epicormic shoots.

In spite of the evident efficiency of using reinvigorated propagules in the vegetative rescue of native tree species, studies on these techniques are still scarce (Bitencourt et al., 2009; Dias et al., 2015b).

Table 3. Vegetative rescue by air layering in Brazilian native tree species.

\begin{tabular}{lcccc}
\hline Origen & IBA $^{(1)}$ growth regulator & Efficiency $^{(2)}(\%)$ & Species & Reference \\
\hline Crown shoots & $1,000 \mathrm{mg} \mathrm{L}^{-1}$ & 100.0 & Bixa orellana & Mantovani et al. (2010) \\
& $*$ & 100.0 & Anacardium occidentale & Almeida et al. (1990) \\
& 500 and $2,000 \mathrm{mg} \mathrm{L}^{-1}$ & 16.7 & Calophyllum brasiliense & Leite et al. (2007) \\
& $6,000 \mathrm{mg} \mathrm{L}^{-1}$ & 75.0 & Cnidoscolus quercifolius & Campos et al. (2015) \\
& $0,500,1,000$, and $2,000 \mathrm{mg} \mathrm{kg}^{-1}$ & 0.0 & Campomanesia xanthocarpa & Teleginski (2016) \\
6,000 and $4,000 \mathrm{mg} \mathrm{L}^{-1}$ & 100.0 & Plinia trunciflora & Danner et al. (2006) \\
$4,000 \mathrm{mg} \mathrm{L}^{-1}$ & 87.5 & Plinia cauliflora & Sasso et al. (2010) \\
$4,000 \mathrm{mg} \mathrm{L}^{-1}$ & - & Schinus terebinthifolius & Gonçalves et al. (2007) \\
& $10,000 \mathrm{mg} \mathrm{L}^{-1}$ & Spondias tuberosa & Lederman et al. (1991) \\
\hline
\end{tabular}

${ }^{(1)}$ IBA, indole butyric acid. ${ }^{(2)}$ Efficiency of rooting. *No application of the growth regulator. -, no information available.

Table 4. Vegetative rescue using rooting cuttings of epicormic shoots in Brazilian native tree species.

\begin{tabular}{|c|c|c|c|c|}
\hline Origen & IBA $^{(1)}$ growth regulator & Efficiency $^{(2)}(\%)$ & Species & Reference \\
\hline \multirow[t]{10}{*}{ Basal sprouts } & $6,000 \mathrm{mg} \mathrm{L}^{-1}$ & 38.5 & Anadenanthera macrocarpa & Dias et al. (2015b) \\
\hline & - & $<30.0$ & Araucaria angustifolia & Wendling \& Brondani (2015) \\
\hline & $1,000 \mathrm{mg} \mathrm{L}^{-1}$ & 83.3 & Calophyllum brasiliense & Ciriello \& Mori (2015) \\
\hline & $6,000 \mathrm{mg} \mathrm{L}^{-1}$ & 65.0 & Calophyllum brasiliense & Kratz et al. (2016) \\
\hline & - & 25.5 & Campomanesia xanthocarpa & Teleginski (2016) \\
\hline & - & 87.5 & Eremanthus erythropappus & Rezende (2007) \\
\hline & - & 65.5 & Ilex paraguariensis & Bitencourt et al. (2009) \\
\hline & $3,000 \mathrm{mg} \mathrm{L}^{-1}$ & 70.6 & Ilex paraguariensis & Stuepp et al. (2015) \\
\hline & - & 88.7 & Ilex paraguariensis & Stuepp et al. (2017a) \\
\hline & - & 81.0 & Vochysia bifalcata & Rickli et al. (2015) \\
\hline \multirow[t]{3}{*}{ Pruned canopy } & - & $<30.0$ & Araucaria angustifolia & Wendling \& Brondani (2015) \\
\hline & - & 0.0 & Campomanesia xanthocarpa & Teleginski (2016) \\
\hline & - & 20.4 & Erythrina falcata & Neves et al. (2006) \\
\hline \multirow[t]{2}{*}{ Stem span } & - & 16.93 & Campomanesia xanthocarpa & Teleginski (2016) \\
\hline & - & 31.0 & Vochysia bifalcata & Rickli et al. (2015) \\
\hline $\begin{array}{l}\text { Sprouting of detached } \\
\text { branches kept in a greenhouse }\end{array}$ & - & $44.4 \%$ & Campomanesia xanthocarpa & Teleginski (2016) \\
\hline
\end{tabular}

${ }^{(1)}$ IBA, indole butyric acid. ${ }^{(2)}$ Efficiency of the technique. -, no information available. 
The use of this type of propagule can increase not only rooting success but also the physiological quality of the plants produced, reflecting in an increase in vegetative and radicular vigor (Stuepp et al., 2015).

\section{Vegetative propagation in Brazilian native tree species}

The main difference between vegetative rescue and vegetative propagation is how each technique is applied. While the purpose of rescue is to obtain at least one individual genetically identical to the parent plant, vegetative propagation aims to produce a larger number of copies (clones) on a commercial scale or not, using methodologies that favor the multiplication of these propagules. In this case, cloning techniques should be recommended for different species and purposes following a logical structure, which should take into account the basic principle of propagule maturation, considering the objective intended for each species and scenario.

Vegetative propagation or cloning has been an excellent tool for forest production in Brazil, where it has increased the productivity of forests planted with non-native species, mainly Eucalyptus spp., consolidating clonal forestry. However, regarding the vegetative propagation of native tree species, a better understanding of the intended objectives, purposes, and propagation techniques applied is still necessary.

In general, studies evaluating the vegetative propagation of Brazilian native tree species have been of an experimental nature. The exception are researches about a few species with consolidated clonal planting like $H$. brasiliensis and Theobroma cacao L., among others, which are nearly always justified by environmental interests such as the restoration of degraded ecosystems. This technique is an important tool for species with limitations in their sexual propagation (Stuepp et al., 2015); however, although the potential of rooting has been assessed in several families, genera, and species with this characteristic, there are no known reports on the viability of applying vegetative propagation under field conditions.

The vegetative propagation of native tree species can be divided into two groups, according to its purposes (Figure 1), which may be: environmental, for plant production; and productive, for the production of any product of forest origin, timber or non-timber. An overview of each of these purposes is presented subsequently, seeking to relate the use of propagation techniques to the objectives established for native tree species.

\section{Vegetative propagation from juvenile parents (seedlings)}

Juvenile plants obtained from seed propagation are frequently used to provide propagules of native tree species (Gratieri-Sossella et al., 2008; Lattuada et al., 2011). The reason for this is the greater ease of rooting of these propagules and also of meeting the desired objectives, considering the greater limitations involved in the vegetative propagation of adult plants (Wendling et al., 2014b).

Although used for the vegetative propagation of native tree species, this type of propagule is better supported for environmental purposes, when the main objective is to obtain the greatest genetic variability as possible. In this case, it is necessary to guarantee genetic variability for the restoration of degraded ecosystems. For this, propagules should be collected from a large number of mother trees, respecting the distance between them. According to the literature, the minimum number of unrelated regional mother trees required for environmental projects varies between 25 (Wendling et al., 2005) and 50 (Carpanezzi \& Carpanezzi, 2006). In general, the use of as many mother trees as possible is recommended, avoiding the formation of a large number of clones from the same mother tree.

For productive purposes, however, this technique presents some limitations since the expression of the genetic characteristics of the plants in their adult phase is still unknown. This is important because parent plants are usually assessed for productive purposes in their adult phase, when their phenotypic characteristics start being expressed. However, the use of juvenile plants may be an excellent alternative when there is availability of genetically improved seeds (controlled crosses) or for the maintenance of seedlings pruned in nurseries, concomitant with their field evaluation, as verified for the genera Pinus spp., for example (Xavier et al., 2013).

Plants of native tree species have been cloned using juvenile propagules, as shown in a number of studies (Table 5). In most of them, high rooting percentages were observed, justified by the greater juvenility of the propagules. 


\section{Vegetative propagation from adult mother trees}

Cuttings, mini-cuttings, and grafting have been used and recommended for the macropropagation of native tree species (Figure 1). These techniques clearly supply the need for qualification in mass production; however, they show marked differences regarding the productivity and physiological quality of the produced propagules, resulting in different multiplication potentials and, particularly, vegetative and root vigor.

In the case of cuttings, the technique alone does not meet the mass propagation objective, requiring adequate methodologies for propagule production through the formation of clonal hedges and selected genetic material. Clonal hedges consist of clonal clusters of plants sown directly in the soil under field or nursery conditions for the production of genetically superior propagules (Xavier et al., 2013). The use of clonal hedges in the production of native tree species is not frequent, and most of the studies developed with these species are experimental and do not require the application of mass propagation techniques (Table 5).

In $H$. brasiliensis, clonal hedges were basically adopted in the production of grafting stems (Lemos
Filho et al., 1994). However, with increasing technology and the qualification of propagation environments, by the 1960 s, plants produced by cuttings were also used (Tinley \& Garner, 1960). Currently, for Hevea spp., it has been shown that clones produced by cuttings have greater morphological quality, both for the root and shoot, than those obtained by grafting and also require a shorter production period (Monteiro et al., 2015). Among the few studies on the use of clonal hedges, stand out those with the species $A$. angustifolia (Wendling et al., 2016c), Cariniana estrellensis Kuntze (Hernandez et al., 2013), H. brasiliensis (Tinley \& Garner, 1960), Piptadenia gonoacantha J.F.Macbr. (Hernández et al., 2012), Schizolobium amazonicum Huber ex Ducke (Dias et al., 2015a), and T. cacao (Faria \& Sacramento, 2003) (Table 5).

In spite of the low use in native species, experimental clonal hedges have presented high potential for propagule production, allowing adequate nutritional and phytosanitary management. The productivity and rooting indexes obtained were also greater than those found for vegetative rescue techniques.

Mini-clonal hedges consist of a set of clones established in protected environments under pruning and controlled nutritional management, according to

Table 5. Application of the cuttings technique as a method of mass propagation applied to Brazilian native tree species.

\begin{tabular}{|c|c|c|c|c|}
\hline Propagule $^{(1)}$ & Growth regulator & Efficiency $(\%)$ & Species & Reference \\
\hline & \multicolumn{4}{|c|}{ Juvenile plants (seedlings) } \\
\hline Juvenile & - & 77.5 & Annona glabra & Scaloppi Junior (2007) \\
\hline Juvenile & 3,000 and $5,000 \mathrm{mg} \mathrm{L}^{-1} \mathrm{IBA}^{(2)}$ & 19.4 & Araucaria angustifolia & Iritani et al. (1986) \\
\hline Juvenile & 3,000 and $7,000 \mathrm{mg} \mathrm{L}^{-1} \mathrm{IBA}$ & 90.0 & Calophyllum brasiliense & Ciriello \& Mori (2015) \\
\hline Juvenile & - & 73.3 & Erythrina falcata & Neves et al. (2006) \\
\hline Juvenile & - & 69.1 & Eugenia uniflora & Lattuada et al. (2011) \\
\hline Juvenile & - & 90.0 & Hevea brasiliensis & Baptist (1939) \\
\hline Juvenile & - & 100.0 & Hevea brasiliensis & Muzik \& Cruzado (1956) \\
\hline Juvenile & $200 \mathrm{mg} \mathrm{L}^{-1} \mathrm{IBA} / 12$ hours & 66.6 & Hevea brasiliensis & Castro et al. (1984) \\
\hline Juvenile & - & 42.0 & Ilex paraguariensis & Graça et al. (1988) \\
\hline Juvenile & $2,000 \mathrm{mg} \mathrm{L}^{-1} \mathrm{IBA}+$ saccharose $1 \%$ & 0.0 & Ocotea puberula & Silva (1984) \\
\hline Juvenile & - & 40.5 & Rollinia mucosa & Scaloppi Junior (2007) \\
\hline Juvenile & - & 25.0 & Rollinia sp. & Scaloppi Junior (2007) \\
\hline \multirow[t]{2}{*}{ Juvenile } & $6,000 \mathrm{mg} \mathrm{L}^{-1} \mathrm{IBA}$ & 100.0 & Theobroma cacao & Sodré \& Corá (2007) \\
\hline & \multicolumn{4}{|c|}{ Clonal hedge } \\
\hline Adult & $3,000 \mathrm{mg} \mathrm{L}^{-1} \mathrm{IBA}$ & 53.7 & Araucaria angustifolia & Wendling et al. (2016c) \\
\hline Adult & - & $>70.0$ & Cariniana estrellensis & Hernandez et al. (2013) \\
\hline Adult & - & $<90.0$ & Hevea brasiliensis & Tinley \& Garner (1960) \\
\hline Juvenile & - & 100.0 & Piptadenia gonoacantha & Hernández et al. (2012) \\
\hline Adult & $32,000 \mathrm{mg} \mathrm{L}^{-1} \mathrm{IBA}$ & 88.9 & Schizolobium amazonicum & Dias et al. (2015a) \\
\hline Adult & $6,000 \mathrm{mg} \mathrm{L}^{-1} \mathrm{IBA}$ & 100.0 & Theobroma cacao & Faria \& Sacramento (2003) \\
\hline
\end{tabular}

${ }^{(1)}$ Juvenile, seminal stump propagules, formed from seedlings; and adult, clonal stump propagule, formed with clones from adult mother trees. ${ }^{(2)}$ IBA, indole butyric acid. 
the characteristics of the species. Mini-cuttings is an evolution of the cuttings technique, differing mainly as to the nutritional and phytosanitary control of the produced propagules. The system most applied in forest species has been the denominated semihydroponic, composed of a channel containing inert substrate (sand) to support the mini-stumps (Wendling et al., 2007; Xavier \& Silva, 2010). However, in native species, the establishment of mini-clonal hedges in pots, tubes, or polyethylene boxes has been tested frequently (Xavier et al., 2003a, 2003b; Peña Peña et al., 2015; Peña, 2015). Considering that plant nutritional management is limited to the area available for root development, the greatest difference between these two systems lies in the productive capacity and vigor of the propagules.

In mini-clonal hedges, rooting percentage is used to qualify propagule production. For Erythrina cristagalli L., for example, while semi-hardwood cuttings from crown shoots showed rooting below $10 \%$, minicuttings reached $100 \%$ (Gratieri-Sossella et al., 2008). However, it should be pointed out that, in this case, efficiency is not only linked to the mini-cuttings technique, but also directly to the maturity of the ministumps, i.e., rooting percentages tend to be higher when juvenile mini-stumps are used, rather than adult propagules.

Regardless of the environment where mini-stumps are cultivated, the well-managed mini-clonal hedge is the basis for success in the mass propagation of forest species. However, this technique is still underused due to the reduced number of native tree species with selected genetic material available for scaling. Its application is almost entirely for experimental purposes, but is supported by good results for several species (Table 6).

Similar to the cuttings technique, grafting can be used both for the vegetative rescue of genetic genotypes of interest and for propagation on a commercial scale (Pereira \& Leal, 2012; Wendling et al., 2017b). Grafting, as a propagation technique, has a wide application in native species, especially in fruit trees, when the main objective is to maintain the maturity of the propagules (Moreira Filho \& Ferreira, 2009), resulting in early flowering and, therefore, early production, besides reducing plant size (Wendling et al., 2017b).

Grafting has been the main technique used to clone $H$. brasiliensis since the beginning of the $20^{\text {th }}$ century. Already in the initial studies, the viability of the technique became evident, resulting in up to $81.1 \%$ of plant formation (Mendes, 1959). Currently, grafting has been applied to $H$. brasiliensis through the method of budding in seminal rootstocks (Cardinal et al., 2007) using green stems (grafting buds) produced in a clonal garden (Pereira \& Leal, 2012). Some studies have sought to evaluate the potential of the mini-clonal hedge technique for viable stem production for Hevea spp. grafting, with promising results for shoot yield and graft survival (Borelli, 2016).

The first studies on the viability of grafting in A. angustifolia date from the late 1960 s to the mid1970s (Gurgel \& Gurgel-Filho, 1967; Kageyama \& Ferreira, 1975). Since then, the technique has been improved (Wendling, 2011; Zanette et al., 2011), presenting percentages of survival greater than $90 \%$ by patch grafting with orthotropic buds originating from female stem apex sprouts (Wendling et al., 2016a).

The qualification of the grafting technique has also been assessed for other species (Table 7).

\section{Clonal forests of Brazilian native tree species}

For the genera Eucalyptus, clonal forestry is already established and is in commercial expansion in Brazil, constituting the pillar of the timber, energy, biomass, and, mainly, paper and pulp industry. However, with rare exceptions, native species with high silvicultural potential have been neglected by the Brazilian forestry sector.

Studies related to clonal forestry of native species have been concentrated in forest research institutions, and are mostly in the initial stages of collection and evaluation of seminal plantations, i.e., progeny and provenance assays (Pinto Júnior et al., 2013). Although there is a considerable evolution in clonal forestry for some species, including the selection of genetic material and assessments at the clonal field level, no works been carried out to disseminate such information.

Furthermore, even though vegetative propagation has been made viable for many species, little or nothing is known about their growth in the field. Among these species, several have shown potential for the application of the technique, including: C. estrellensis, $P$. gonoacantha, S. amazonicum, Anadenanthera macrocarpa (Benth.) Brenan, Calophyllum brasiliense Cambess., Calycophyllum spruceanum (Benth.) 
K.Schum., C. estrellensis, Cordia trichotoma (Vell.) Steud., Piptocarpha angustifolia Dusén ex Malme, S. amazonicum, and Schizolobium parahyba (Vell.) Blake (Tables 6 and 7).

Of the small number of native tree species with known clonal forestry, $H$. brasiliensis is the most evaluated. Studies on the species were initiated in the last century, assessing the rooting capacity of different genetic materials (Muzik \& Cruzado, 1956; Tinley \& Garner, 1960). Advances in the clonal forestry of $H$. brasiliensis trees yielded satisfactory productivity indexes, with average productivity increasing from
$400 \mathrm{~kg} \mathrm{ha} \mathrm{h}^{-1}$ per year for seminal plantations to $2,500 \mathrm{~kg} \mathrm{ha}^{-1}$ per year for clonal plantations (Gonçalves \& Fontes, 2009). Over the last few decades, in addition to the production of latex, there has been an attempt to include wood quality in breeding programs, considering the wood supply during the reformulation of plantations (Leonello et al., 2012).

Ilex paraguariensis has recently been included in the list of native species with proven potential in clonal forestry (Santin et al., 2015; Wendling \& Brondani, 2015; Sturion et al., 2017). Although it is still under evaluation in the field, it has presented promising

Table 6. Application of the mini-cuttings technique as a mass propagation method applied to Brazilian native tree species.

\begin{tabular}{|c|c|c|c|c|}
\hline Propagule $^{(1)}$ & Growth regulator & Efficiency $(\%)$ & Species & Reference \\
\hline & \multicolumn{4}{|c|}{ Mini-clonal hedge } \\
\hline Juvenile & - & 98.0 & Anadenanthera macrocarpa & Dias et al. (2012) \\
\hline Juvenile & $1,500 \mathrm{mg} \mathrm{L}^{-1} \mathrm{IBA}^{(2)}$ & 32.0 & Araucaria angustifolia & Pires et al. (2013) \\
\hline Juvenile & - & 83.0 & Araucaria angustifolia & Pires et al. (2015) \\
\hline Juvenile & - & 95.8 & Calophyllum brasiliense & Silva et al. (2010) \\
\hline Juvenile & - & 100.0 & Calycophyllum spruceanum & Gatti (2002) \\
\hline Juvenile & $2,000 \mathrm{mg} \mathrm{L}^{-1} \mathrm{NAA}^{(3)}$ & 83.3 & Cariniana estrellensis & Gatti et al. (2011) \\
\hline Juvenile & - & 84.0 & Cedrela fissilis & Xavier et al. (2003b) \\
\hline Juvenile & - & 79.0 & Cedrela fissilis & Xavier et al. (2003a) \\
\hline Juvenile & - & 100.0 & Cordia trichotoma & Carneiro (2013) \\
\hline Juvenile & $30 \mathrm{mmol} \mathrm{L}^{-1} \mathrm{IBA}$ & $>45.0$ & Cordia trichotoma & Kielse et al. (2013) \\
\hline Juvenile & - & 38.3 & Cordia trichotoma & Kielse et al. (2015) \\
\hline- & $1,000 \mathrm{mg} \mathrm{L}^{-1} \mathrm{IBA}$ & 13.3 & Cordia trichotoma & Kielse et al. (2015) \\
\hline Juvenile & - & - & Dipteryx alata & Martins et al. (2012) \\
\hline Juvenile & - & 25.0 & Eremanthus erythropappus & Rezende (2007) \\
\hline Juvenile & $2,000,3,000$, and $4,000 \mathrm{mg} \mathrm{L}^{-1} \mathrm{IBA}$ & 100.0 & Erythrina crista-galli & Gratieri-Sossella et al. (2008) \\
\hline Juvenile & - & 85.5 & Erythrina falcata & Cunha et al. (2008) \\
\hline Adult & - & 1.9 & Eugenia uniflora & Peña Peña et al. (2015) \\
\hline Juvenile & $2,500 \mathrm{mg} \mathrm{L}^{-1} \mathrm{IBA}$ & 97.2 & Eugenia uniflora & Peña et al. (2015) \\
\hline Juvenile & - & 100.0 & Handroanthus heptaphyllus & Oliveira et al. (2015b) \\
\hline Juvenile & - & 80.0 & Handroanthus heptaphyllus & Oliveira et al. (2015a) \\
\hline Juvenile & - & 90.0 & Ilex paraguariensis & Wendling et al. (2007) \\
\hline Juvenile & - & 77.5 & Ilex paraguariensis & Brondani et al. (2007) \\
\hline Adult & $8,000 \mathrm{mg} \mathrm{L}^{-1} \mathrm{IBA}$ & 62.5 & Ilex paraguariensis & Brondani et al. (2008) \\
\hline Adult & - & - & Ilex paraguariensis & Nagaoka et al. (2013) \\
\hline Adult & - & 68.7 & Ilex paraguariensis & Kratz et al. (2015) \\
\hline Juvenile & - & 94.3 & Maytenus ilicifolia & Lima et al. (2009) \\
\hline Juvenile & - & 45.0 & Piptocarpha angustifolia & Ferriani et al. (2011) \\
\hline Juvenile & - & 71.3 & Piptocarpha angustifolia & Stuepp et al. (2017c) \\
\hline Juvenile & - & 58.7 & Piptocarpha angustifolia & Stuepp et al. (2016b) \\
\hline Juvenile & - & 31.4 & Plathymenia foliolosa & Neubert (2014) \\
\hline Juvenile & - & 92.0 & Psidium cattleianum & Altoé et al. (2011) \\
\hline Juvenile & - & 96.0 & Psidium guineense & Altoé et al. (2011) \\
\hline Juvenile & - & 80.6 & Sapium glandulatum & Ferreira et al. (2010) \\
\hline Juvenile & - & $>60.0$ & Schizolobium amazonicum & Souza (2015) \\
\hline Juvenile & - & $>35.0$ & Schizolobium parahyba & Souza (2015) \\
\hline
\end{tabular}

(1) Juvenile, seminal stump propagules, formed from seedlings; and adult, clonal stump propagule, formed with clones from adult mother trees. ${ }^{(2)}$ IBA, indole butyric acid. ${ }^{(3)} \mathrm{NAA}$, naphthaleneacetic acid. 
results (Santin et al., 2015). Due to its multiple-use purpose (leaves, branches, and wood), studies about $I$. paraguariensis clones have been extensive (Rakocevic et al., 2006; Santin et al., 2015). The obtained results show that clonal plants produced by the cuttings and mini-cuttings techniques present higher survival and productivity compared with seedlings, as well as leaves and thin branches up to $7 \mathrm{~mm}$ (Rakocevic et al., 2006; Santin et al., 2015), indicating its suitability for the clonal production of the species.

Araucaria angustifolia presents very interesting characteristics for Brazilian silviculture, not only regarding its already-proven superior wood quality but also the high productive potential of its seeds (pine nuts), appreciated as food. The clonal forestry of the species has followed two lines for plant production, both already assessed in the field: grafting technique, using juvenile and adult grafts for wood and nut production, respectively; and cuttings, using juvenile shoots from selected plants for wood production (Wendling et al., 2016a, 2016b, 2017b). Araucaria angustifolia clones showed larger diameter at breast height (DBH) and an increase in total height compared with seminal plantations (Wendling et al., 2016b); the authors concluded that female clones produced by apical cuttings were superior to the others. In comparison with plants grafted directly in the field with juvenile propagules (basal shoots of adult trees) and seedlings, the clones were once again superior regarding DBH and total height (Wendling et al., 2017a). These authors also concluded that cuttings and grafting are potential techniques for $A$. angustifolia plant production for logging purposes. In this case, grafting stands out, being recommended for its low cost and for the formation of orchards aiming seed production, resulting in a volumetric increase and a form factor similar to that of seedlings.

Some native species, particularly fruit, have been the focus of the silvicultural evaluations of clonal plantations, especially T. cacao (Almeida et al., 2009) and Theobroma grandiflorum (Willd. ex Spreng.) K.Schum. (Souza et al., 2002). Despite including

Table 7. General application of grafting for vegetative rescue and multiplication of Brazilian native tree species.

\begin{tabular}{|c|c|c|c|c|}
\hline Propagule & Grafting technique & Survival (\%) & Species & Reference \\
\hline Crown & Side stub & 27.0 & Araucaria angustifolia & Gurgel \& Gurgel-Filho (1967) \\
\hline Crown & Whip-and-tongue & 0.0 & Araucaria angustifolia & Gurgel \& Gurgel-Filho (1967) \\
\hline Crown & Top cleft & 90.0 & Araucaria angustifolia & Kageyama \& Ferreira (1975) \\
\hline Crown & Side stub & $<60.0$ & Araucaria angustifolia & Kageyama \& Ferreira (1975) \\
\hline Crown & Whip graft & 40.0 & Araucaria angustifolia & Kageyama \& Ferreira (1975) \\
\hline Crown & Patch & 100.0 & Araucaria angustifolia & Kageyama \& Ferreira (1975) \\
\hline Base & Patch & 65.0 & Araucaria angustifolia & Zanette et al. (2011) \\
\hline Young plants & Patch & 93.0 & Araucaria angustifolia & Constantino \& Zanette (2015) \\
\hline Crown & Patch & $<90.0$ & Araucaria angustifolia & Wendling et al. (2016a) \\
\hline Crown & Patch & - & Bertholletia excelsa & Müller (1982) \\
\hline Crown & Top cleft & 87.5 & Eugenia uniflora & Franzon et al. (2010) \\
\hline Crown & Top cleft & 100.0 & Genipa americana & Prado Neto (2006) \\
\hline Crown & Side stub & 95.4 & Genipa americana & Prado Neto (2006) \\
\hline Crown & Approach & 100.0 & Hevea brasiliensis & Mendes (1959) \\
\hline Crown & Top cleft & 74.0 & Hevea brasiliensis & Lemos Filho et al. (1994) \\
\hline Crown & Patch & - & Hevea brasiliensis & Cardinal et al. (2007) \\
\hline Mini-clonal hedges & Patch & $>70.0$ & Hevea brasiliensis & Borelli (2016) \\
\hline Crown & Top cleft & 80.0 & Ilex paraguariensis & Oliszeski \& Neiverth (2002) \\
\hline Crown & Top cleft & $<68.0$ & Ilex paraguariensis & Santin et al. (2015) \\
\hline Crown & Side stub & 65.0 & Myrciaria dubia & Ferreira \& Gentil (1997) \\
\hline Crown & Side stub & 89.3 & Myrciaria dubia & Moreira Filho \& Ferreira (2009) \\
\hline Crown & Top cleft & 70.0 & Plinia trunciflora & Malagi et al. (2012) \\
\hline Crown & Top cleft & 69.2 & Plinia cauliflora & Sasso et al. (2010) \\
\hline Crown & Top cleft & 72.9 & Plinia jaboticaba & Sasso et al. (2010) \\
\hline Crown & Patch & 78.0 & Spondias tuberosa & Pedrosa et al. (1991) \\
\hline Crown & Side stub & 95.0 & Theobroma grandiflorum & Venturieri et al. (1986/1987) \\
\hline
\end{tabular}


woody species, breeding programs of these species have focused exclusively on fruit production (Almeida et al., 2009; Souza et al., 2002).

Brazil presents an immense range of native species with silvicultural potential, either for the production of wood or non-wood products. However, few species were actually successful in Brazilian silviculture. In the case of clonal forestry, the number of species analyzed in the field is even lower, generally due to the lack of knowledge about the productive potential of these materials and the unavailability of resources for this purpose, such as planting area, plants, and labor. Despite the information available about the vegetative propagation of many native tree species, studies on the topic usually begin without an adequate genetic selection, making it difficult to evaluate quality genetic materials under field conditions. However, the assessment of woody species propagation is key to enable clonal forestry, depending on, among other factors, the continuity of studies in the field, even if at experimental levels.

Therefore, there is an evident gap to be filled in Brazilian clonal forestry regarding the use of native tree species. To increase the insertion of these species, a greater integration between studies on the vegetative propagation and vigor of these materials in the field is necessary; otherwise, the use of these species, whether for environmental or productive purposes, will always be limited to the experimental stage.

\section{Concluding remarks}

Vegetative rescue in native trees is feasible for a significant number of species, as long as there is a consistency in the choice of the applied technique and the intended objectives. For this, a better understanding of the different stages and purposes involved in the vegetative propagation of native tree species is necessary. In studies where the objective is the production of flowers, fruits or seeds, it is essential to identify techniques that maintain the maturity of the propagules. However, if the objective is the restoration of degraded ecosystems and the production of wood and leaves, techniques that facilitate vegetative propagation, offering greater juvenility of the propagules, are desired. The lack of experiments in field conditions, i.e., less than $10 \%$ for the species cited in this review, is evidence of the need to increase the number of species evaluated in the clonal forestry of Brazilian native species. Specifically for environmental purposes, studies comparing multiple species using standard methods of analysis and research material (type and origin of propagules) are recommended, enabling a better understanding and more efficient application of the vegetative propagation techniques.

\section{Acknowledgments}

To Coordenação de Aperfeiçoamento de Pessoal de Nível Superior (Capes), for financial support (process number 1340661).

\section{References}

ALMEIDA, C.M.V.C. de; DIAS, L.A. dos S.; SILVA, A. de P. Caracterização agronômica de acessos de cacau. Pesquisa Agropecuária Brasileira, v.44, p.368-373, 2009. DOI: 10.1590/ S0100-204X2009000400006.

ALMEIDA, F.C.G.; ALMEIDA, F.A.G.; ALMEIDA, F.F.G.; CARVALHO, P.R.D. Influência do estiolamento e do ácido indolebutírico na formação de raízes do alporque de cajueiro anão precoce (Anacardium occidentale L.). Acta Botânica Brasilica, v.4, p.9-12, 1990. DOI: 10.1590/S0102-33061990000300002.

ALTOÉ, J.A.; MARINHO, C.S.; COSTA TERRA, M.I. da; BARROSO, D.G. Propagação de araçazeiro e goiabeira via miniestaquia de material juvenil. Bragantia, v.70, p.312-318, 2011. DOI: $10.1590 / \mathrm{S} 0006-87052011000200009$.

BAPTIST, E.D.C. Plant hormones. Journal of the Rubber Research Institute of Malaysia, v.9, p.17-39, 1939.

BERNHARDT, R. Análise quantitativa e qualitativa do crescimento de caixeta-Tabebuia cassinoides (LAM.) DC. em florestas manejadas, no Município de Iguape/SP. 2003. 61p. Dissertação (Mestrado) - Universidade de São Paulo, Piracicaba.

BITENCOURT, J.; ZUFFELLATO-RIBAS, K.C.; WENDLING, I.; KOEHLER, H.S. Enraizamento de estacas de erva-mate (Ilex paraguariensis A. St.-Hill.) provenientes de brotações rejuvenescidas. Revista Brasileira de Plantas Medicinais, v.11, p.277-281, 2009. DOI: 10.1590/S1516-05722009000300008.

BORELLI, K. Produção de mudas de seringueira em viveiro suspenso. 2016. 87p. Dissertação (Mestrado) - Universidade de São Paulo, Piracicaba.

BRONDANI, G.E.; ARAUJO, M.A. de; WENDLING, I.; KRATZ, D. Enraizamento de miniestacas de erva-mate sob diferentes ambientes. Pesquisa Florestal Brasileira, n.57, p.29-38, 2008.

BRONDANI, G.E.; WENDLING, I.; SANTIN, D.; BENEDETTI, E.L.; ROVEDA, L.F.; ORRUTÉA, A.G. Ambiente de enraizamento e substratos na miniestaquia de erva-mate. Scientia Agraria, v.8, p.257-267, 2007.

CAMPOS, G.N.F.; ARRIEL, E.F.; NOBERTO, M.N.S.; FARIAS JUNIOR, J.A.; SILVA, V.V.M.; FREIRE, A.L.O. Clonagem de 
Cnidoscolus quercifolius por alporquia. Ciência Florestal, v.25, p.743-749, 2015. DOI: 10.5902/1980509819677.

CARDINAL, A.B.B.; GONÇALVES, P. de S.; MARTINS, A.L.M. Influência de seis porta-enxertos sobre a produção de clones superiores de seringueira. Bragantia, v.66, p.277-284, 2007. DOI: $10.1590 / \mathrm{S} 0006-87052007000200011$.

CARNEIRO, M.A. Crescimento inicial e propagação vegetativa de Cordia trichotoma (Vellozo) Arrabida Ex Steudel (louropardo). 2013. 65p. Tese (Doutorado) - Universidade Federal da Grande Dourados, Dourados.

CARPANEZZI, A.A.; CARPANEZZI, O.T.B. Espécies nativas recomendadas para recuperação ambiental no Estado do Paraná, em solos não degradados. Colombo: Embrapa Florestas, 2006. 52p. (Embrapa Florestas. Documentos, 136).

CASTRO,P.R.C.; FACHINELLO, J.C.; FAQUIM, V.; RAMALHO, J.F.G.P.; BACCHI, O.O.S. Estimulação do enraizamento de estacas de seringueira (Hevea brasiliensis Muell. Arg.). Anais da Escola Superior de Agricultura Luiz de Queiroz, v.41, p.349357, 1984. DOI: 10.1590/S0071-12761984000100020.

CIRIELLO, E.; MORI, E.S. Rooting of guanandi (Calophyllum brasiliense Cambess) cuttings using indole-butyric acid. Cerne, v.21, p.641-648, 2015. DOI: 10.1590/01047760201521041803.

CONSTANTINO, V.; ZANETTE, F. Produção de borbulhas ortotrópicas para enxertia de Araucaria angustifolia. Acta Biológica Paranaense, v.44, p.49-55, 2015. DOI: 10.5380/abpr. v44i1-4.47598.

CUNHA, A.C.M.C.M. da; WENDLING, I.; SOUZA JÚNIOR, L. Miniestaquia em sistema de hidroponia e em tubetes de corticeira-do-mato. Ciência Florestal, v.18, p.85-92, 2008. DOI: $10.5902 / 19805098513$.

DANNER, M.A.; CITADIN, I.; FERNANDES JUNIOR, A. de A.; ASSMAN, A.P.; MAZARO, S.M.; DONAZZOLO, J.; SASSO, S.A.Z. Enraizamento de jabuticabeira (Plinia trunciflora) por mergulhia aérea. Revista Brasileira de Fruticultura, v.28, p.530-532, 2006. DOI: 10.1590/S0100-29452006000300043.

DIAS, P.C.; ATAÍDE, G. da M.; XAVIER, A.; OLIVEIRA, L.S. de; PAIVA, H.N. de. Propagação vegetativa de Schizolobium amazonicum por estaquia. Cerne, v.21, p.379-386, 2015a. DOI: 10.1590/01047760201521031467.

DIAS, P.C.; XAVIER, A.; OLIVEIRA, L.S. de; FÉLIX, G. de A.; PIRES, I.E. Resgate vegetativo de árvores de Anadenanthera macrocarpa. Cerne, v.21, p.83-89, 2015b. DOI: 10.1590/01047760201521011381.

DIAS, P.C.; XAVIER, A.; OLIVEIRA, L.S. de; PAIVA, H.N. de; CORREIA, A.C.G. Propagação vegetativa de progênies de meiosirmãos de angico-vermelho (Anadenanthera macrocarpa (Benth) Brenan) por miniestaquia. Revista Árvore, v.36, p.389-399, 2012. DOI: 10.1590/S0100-67622012000300001.

FARIA, J.C.; SACRAMENTO, C.K. do. Enraizamento e crescimento de estacas herbáceas do cacaueiro (clones Cepec 42, TSH 516 e TSH 1188) em função da aplicação do ácido indolbutírico (AIB). Revista Brasileira de Fruticultura, v.25, p.192-194, 2003.
FERREIRA， B.G.A.; ZUFFELLATO-RIBAS， K.C.; WENDLING, I.; KOEHLER, H.S.; NOGUEIRA, A.C. Miniestaquia de Sapium glandulatum (Vell.) Pax com o uso de ácido indol butírico e ácido naftaleno acético. Ciência Florestal, v.20, p.19-31, 2010. DOI: 10.5902/198050981758.

FERREIRA, S.A. do N.; GENTIL, D.F. de O. Propagação assexuada do camu-camu (Myrciaria dubia) através de enxertias do tipo garfagem. Acta Amazonica, v.27, p.163-168, 1997. DOI: 10.1590/1809-43921997273168.

FERRIANI, A.P.; ZUFFELLATO-RIBAS, K.C.; HELM, C.V.; BOZA, A.; WENDLING, I.; KOEHLER, H.S. Produção de brotações e enraizamento de miniestacas de Piptocarpha angustifolia. Pesquisa Florestal Brasileira, v.31, p.257-264, 2011. DOI: 10.4336/2011.pfb.31.67.257.

FONSECA, C.E.L. da; SPERÂNDIO, J.P.; CORRÊA, M.P.F.; BUENO, D.M.; LIMA, R. Propagação vegetativa do jacarandáda-baía através da estaquia. Pesquisa Agropecuária Brasileira, v.26, p.31-37, 1991

FRANZON, R.C.; GONÇALVES, D. da S.; ANTUNES, L.E.C.; RASEIRA, M. do C.B. Propagação vegetativa de genótipos de pitangueira (Eugenia uniflora L.) do sul do Brasil por enxertia de garfagem. Revista Brasileira de Fruticultura, v.32, p.262-267, 2010. DOI: 10.1590/S0100-29452010005000003.

GATTI, K.C. Propagação vegetativa de pau mulato (Calycophyllum spruceanum (Benth) K. Schum.), jequitibá (Cariniana estrellensis (Raddi) Kuntze) e teca (Tectona grandis Linn. f.) por miniestaquia. 2002. 72p. Tese (Doutorado) - Universidade Federal de Viçosa, Viçosa.

GATTI, K.C.; GONÇALVES, R. de C.; XAVIER, A.; PAIVA, H. de. Propagação vegetativa de jequitibá Cariniana estrellensis (Raddi) por miniestaquia. Temas Agrários, v.16, p.54-63, 2011. DOI: 10.21897/rta.v16i2.691.

GONÇALVES, M. da P.M.; MAÊDA, J.M.; ABREU, H. dos S.; SILVA, S.P.; SOUZA, G.R. de. Propagação vegetativa da aroeira (Schinus terebinthifolius) por alporquia. Revista Brasileira de Biociências, v.5, p.363-365, 2007. Suplemento 2 .

GONÇALVES, P. de S.; FONTES, J.R.A. Domesticação e melhoramento da seringueira. In: BORÉM, A.; LOPES, M.T.G.; CLEMENT, C.R. (Ed.). Domesticação e melhoramento: espécies amazônicas. Viçosa: Ed. da UFV, 2009. p.395-423.

GRAÇA, M.E.C.; COOPER, M.A.; TAVARES, F.R.; CARPANEZZI, A.A. Estaquia de erva-mate. Colombo: Embrapa-CNPF, 1988. 6p. (Embrapa-CNPF. Circular técnica, 18). GRATIERI-SOSSELlA, A.; PETRY, C.; NIENOW, A.A. Propagação da corticeira do banhado (Erythrina crista-galli L.) (Fabaceae) pelo processo de estaquia. Revista Árvore, v.32, p.163-171, 2008. DOI: 10.1590/S0100-67622008000100018.

GURGEL, J.T.A.; GURGEL-FILHO, C.A. Métodos de enxertia para o pinheiro brasileiro Araucaria angustifolia (Bertol.) O. Ktze., visando à formação de pomares de sementes. Silvicultura em São Paulo, v.6, p.153-155, 1967.

HAN, Y.; WANG, Y.; JIANG, H.; WANG, M.; KORPELAINEN, H.; LI, C. Reciprocal grafting separates the roles of the root and shoot in sex-related drought responses in Populus cathayana 
males and females. Plant, Cell \& Environment, v.36, p.356-364, 2013. DOI: $10.1111 /$ j.1365-3040.2012.02578.x.

HERNANDEZ, W.; XAVIER, A.; PAIVA, H.N. de; WENDLING, I. Propagação vegetativa do jequitibá-rosa (Cariniana estrellensis (Raddi) Kuntze) por estaquia. Revista Árvore, v.37, p.955-967, 2013. DOI: $10.1590 /$ S0100-67622013000500018.

HERNÁNDEZ, W.; XAVIER, A.; PAIVA, H.N. de; WENDLING, I. Propagação vegetativa do pau-jacaré (Piptadenia gonoacantha (Mart.) Macbr.) por estaquia. Revista Árvore, v.36, p.813-823, 2012. DOI: 10.1590/S0100-67622012000500003.

IRITANI, C.; SOARES, R.V.; GOMES, A.V. Aspectos morfológicos da ação de reguladores do crescimento em estacas de Araucaria angustifolia (Bert) O. Ktze. Acta Biológica Paranaense, v.15, p.1-20, 1986. DOI: 10.5380/abpr.v15i0.815.

KAGEYAMA, P.Y.; FERREIRA, M. Propagação vegetativa por enxertia em Araucaria angustifolia (Bert) O. Ktze. IPEF, n.11, p.95-102, 1975.

KIELSE, P.; BISOGNIN, D.A.; HAYGERT, K.L.; MELLO, U.S.; PIMENTEL, N.; RAUBE, M.A. Production and rooting of cordia Cordia trichotoma (Vell.) Arrab. ex Steud. mini-cuttings collected from ministumps of asexual and seminal origin. Ciência Rural, v.45, p.1164-1166, 2015. DOI: 10.1590/0103-8478cr20131011.

KIELSE, P.; BISOGNIN, D.A.; HEBERLE, M.; FLEIG, F.D.; XAVIER, A.; RAUBER, M.A. Propagação vegetativa de Cordia trichotoma (Vell.) Arrab. ex Steudel por estaquia radicular. Revista Árvore, v.37, p.59-66, 2013. DOI: 10.1590/S010067622013000100007.

KRATZ, D.; PIRES, P.P.; STUEPP, C.A.; WENDLING, I. Produção de mudas de erva-mate por miniestaquia em substratos renováveis. Revista Floresta, v.45, p.609-616, 2015. DOI: 10.5380/rf.v45i3.36531.

KRATZ, D.; WENDLING, I.; STUEPP, C.A.; KALIL FILHO, A.N. Epicormic shoots induction and rooting cuttings of Calophyllum brasiliense. Cerne, v.22, p.365-372, 2016.

LATTUADA, D.S.; SPIER, M.; SOUZA, P.V.D. de. Prétratamento com água e doses de ácido indolbutírico para estaquia herbácea de pitangueiras. Ciência rural, v.41, p.2073-2079, 2011. DOI: $10.1590 / \mathrm{S} 0103-84782011001200006$.

LEDERMAN, I.E.; BEZERRA, J.E.F.; ASCHOFF, M.N.A.; OLIVEIRA, E.N.M. de; ROSA, J.M.G. Propagação vegetativa do umbuzeiro (Spondias tuberosa Arr. Cam.) e da gravioleira (Annona muricata L.) através da alporquia. Revista Brasileira de Fruticultura, v.13, p.55-58, 1991.

LEITE, G.L.D.; VELOSO, R.V. dos S.; CASTRO, A.C.R. de; LOPES, P.S.N.; FERNANDES, G.W. Efeito do AIB sobre a qualidade e fitossanidade dos alporques de influência da Caryocar brasiliense Camb (Caryocaraceae). Revista Árvore, v.31, p.315320, 2007. DOI: 10.1590/S0100-67622007000200014.

LEMOS FILHO, J.P. de; PEREIRA, J. da P.; MEDRADO, M.S.; COSTA, J.D.; PINTO, H.S. Mini-enxertia da seringueira (Hevea spp.). II. Problemas e avanços na técnica. Pesquisa Agropecuária Brasileira, v.29, p.779-784, 1994.

LEONELlO, E.C.; BALLARIN, A.W.; OHTO, J.M.; PALMA, H.A.L.; ESCOBAR, J.F. Classificação estrutural e qualidade da madeira do clone GT 1 de Hevea brasiliensis Muell. Arg. Floresta e Ambiente, v.19, p.229-235, 2012. DOI: 10.4322/floram.2012.027.

LIMA, D.M. de; TANNO, G.N.; PURCINO, M.; BIASI, L.A.; ZUFFELLATO-RIBAS, K.C.; ZANETTE, F. Enraizamento de miniestacas de espinheira-santa (Maytenusilicifolia Mart. ex Reissek) em diferentes substratos. Ciência e Agrotecnologia, v.33, p.617-623, 2009. DOI: 10.1590/S1413-70542009000200040.

LIMA, D.M.; BIASI, L.A.; ZANETTE, F.; ZUFFELLATORIBAS, K.C.; BONA, C.; MAYER, J.L.S. Capacidade de enraizamento de estacas de Maytenus muelleri Schwacke com a aplicação de ácido indol butírico relacionada aos aspectos anatômicos. Revista Brasileira de Plantas Medicinais, v.13, p.422-438, 2011. DOI: 10.1590/S1516-05722011000400008.

MALAGI, G.; CITADIN, I.; SCARIOTTO, S.; WAGNER JÚNIOR, A.; SACHET, M.R. Enxertia interespecífica de jabuticabeira: influência do tipo de garfo. Ciência Rural, v.42, p.221-224, 2012.

MANTOVANI, N.C.; GRANDO, M.F.; XAVIER, A.; OTONI, W.C. Resgate vegetativo por alporquia de genótipos adultos de urucum (Bixa orellana L.). Ciência Florestal, v.20, p.403-410, 2010. DOI: $10.5902 / 198050982055$.

MARTÍNEZ-BALLESTA, M.C.; ALCARAZ-LÓPEZ, C.; MURIES, B.; MOTA-CADENAS, C.; CARVAJAL, M. Physiological aspects of rootstock-scion interactions. Scientia Horticulturae, v.127, p.112-118, 2010. DOI: 10.1016/j. scienta.2010.08.002.

MARTINS, I.S.; MANTELLI, M.; SANTOS, S.C.; NETTO, A.P.C.; PINTO, F. Estaquia e concentração de reguladores vegetais no enraizamento de Campomanesia adamantium. Revista de Ciências Agrárias, v.38, p.58-64, 2015.

MARTINS, I.S.; MARTINS, R.C.; DIÓGENES, A.G. Produção de miniestacas em minicepas de Dipteryx alata Vogel (Barú). Revista Científica Eletrônica de Engenharia Florestal, v.19, p.109-117, 2012.

MELO, L.A. de; DAVIDE, A.C.; TEIXEIRA, L.A.F. Metodologia para resgate de matrizes e enraizamento de estacas de Eremanthus erythropappus. Cerne, v.18, p.631-638, 2012. DOI: 10.1590/ S0104-77602012000400013.

MENDES, L.O.T. Considerações sobre a enxertia da seringueira. Bragantia, v.18, p.141-159, 1959. DOI: 10.1590/S000687051959000100011.

MIELKE, M.S.; FACHINELLO, J.C.; NACHTIGAL, J.C.; MATIUZ, B.; ENDRES, L.; SANTOS FILHO, B.G. dos. Comportamento fisiológico de goiabeira serrana quando multiplicada por mergulhia de cepa. Scientia Agricola, v.51, p.21-27, 1994. DOI: 10.1590/S0103-90161994000100004.

MONTEIRO, W.R.; MARQUES, J.R.B.; PACHECO, E.R. Produção de mudas de seringueira por meio do enraizamento de estacas coletadas em plantas adultas. Agrotrópica, v.27, p.191198, 2015.

MOREIRA FILHO, M.; FERREIRA, S.A. do N. Clonagem do camu-camu arbustivo em porta-enxertos de camu-camu arbustivo e arbóreo. Revista Brasileira de Fruticultura, v.31, p.1202-1205, 2009. DOI: $10.1590 / \mathrm{S} 0100-29452009000400039$. 
MÜLLER, C.H. Quebra da dormência da semente e enxertia em castanha-do-Brasil. Belém: EMBRAPA-CPATU, 1982. 40p. (EMBRAPA-CPATU. Documentos, 16).

MUZIK, T.J.; CRUZADO, H.J. Formation and rooting of adventitious shoots in Hevea brasiliensis. American Journal of Botany, v.43, p.503-508, 1956. DOI: 10.1002/j.1537-2197.1956. tb10524.x.

NAGAOKA, R.E.; PERES, F.S.B.; CARMO, A.L.M.; GARCIA, F.A. de O. Efeito do AIB no desenvolvimento de mudas clonais em genótipos de erva-mate. Enciclopédia Biosfera, v.9, p.11821191, 2013.

NEUBERT, V. de F. Propagação vegetativa do vinhático (Plathymenia foliolosa Benth) por miniestaquia. 2014. 38p. Dissertação (Magister Scientiae) - Universidade Federal de Viçosa, Viçosa.

NEVES, T. dos S.; CARPANEZZI, A.A.; ZUFFELLATORIBAS, K.C.; MARENCO, R.A. Enraizamento de corticeira-daserra em função do tipo de estaca e variações sazonais. Pesquisa Agropecuária Brasileira, v.41, p.1699-1705, 2006. DOI: 10.1590/ S0100-204X2006001200003.

OLISZESKI, A.; NEIVERTH, D.D. Recuperação de erveiras nativas por enxertia. Boletim de Pesquisa Florestal, n.44, p.127132, 2002.

OLIVEIRA, M.A.; BARROSO, D.G.; LAMÔNICA, K.R.; CARVALHO, V.S.; OLIVEIRA, M.A. de. Efeito do ácido indol3-butírico (AIB) no enraizamento de miniestacas de ipê-roxo (Handroanthus heptaphyllus Mattos). Ciência Florestal, v.25. p.1043-1051, 2015a. DOI: 10.5902/1980509820666.

OLIVEIRA, M.C.; RIBEIRO, J.F. Enraizamento de estacas de Euplassa inaequalis (Pohl) Engl. de mata de galeria em diferentes estações do ano. Bioscience Journal, v.29, p.991-999, 2013.

OLIVEIRA, T.P.D.F.; BARROSO, D.G.; LAMÔNICA, K.R.; CARVALHO, V.S.; de OLIVEIRA, T.P.D.F.; BARROSO, D.G.; LAMÔNICA, K.R.; DE ARAÚJO CARNEIRO, J.G.; DE OLIVEIRA, M.A. Productivity of polyclonal minigarden and rooting of Handroanthus heptaphyllus Mattos minicuttings. Semina: Ciências Agrárias, v.36, p.2423-2432, 2015b. DOI: 10.5433/1679-0359.2015v36n4p2423.

PEDROSA, A.C.; LEDERMAN, I.E.; BEZERRA, J.E.F.; DANTAS, A.P.; GONZAGA NETO, L. Métodos de enxertia do umbuzeiro (Spondias tuberosa Arr. Cam) em viveiro. Revista Brasileira de Fruticultura, v.13, p.59-62, 1991.

PEÑA PEÑA, M.L. Propagação vegetativa de pitangueira (Eugenia uniflora L.) por estaquia e miniestaquia. 2014. 80p. Tese (Doutorado) - Universidade Federal do Paraná, Curitiba.

PEÑA PEÑA, M.L.; ZANETTE, F.; BIASI, L.A. Época de coleta e ácido indolbutírico no enraizamento de miniestacas de pitangueira. Semina: Ciências Agrárias, v.36, p.3055-3068, 2015. DOI: 10.5433/1679-0359.2015v36n5p3055.

PEÑA, M.L.; ZANETTE, F.; BIASI, L.A. Miniestaquia a partir de minicepas originadas por enxertia de pitangueira adulta. Comunicata Scientiae, v.6, p.397-306, 2015. DOI: 10.14295/ CS.v6i3.817.
PEREIRA, J. da P.; LEAL, A.C. Efeito do período de inverno sobre o desempenho da propagação precoce da seringueira (Hevea spp.). Agrotrópica, v.24, p.91-98, 2012.

PINHEIRO, E.; LIBONATI, V.F.; CASTRO, C. de; PINHEIRO, F.S.V. A enxertia de copa na formação de seringais de cultivo nos trópicos úmidos da Amazônia. Belém: FCAP, 1988. 27p. (FCAP. Informe técnico, 13).

PINTO JÚNIOR, J.E.; SANTOS, P.E.T. dos; AGUIAR, A.V. de; KALIL FILHO, A.N.; PALUDZYSZYN FILHO, E.; STURION, J.A.; RESENDE, M.D.V. de; SOUSA, V.A. de. Melhoramento genético de espécies arbóreas na Embrapa Florestas: uma visão histórica. Colombo: Embrapa Florestas, 2013. 109 p. (Embrapa Florestas. Documentos, 259).

PIRES, P.; WENDLING, I.; AUER, C.; BRONDANI, G. Sazonalidade e soluções nutritivas na miniestaquia de Araucaria angustifolia (Bertol.) Kuntze. Revista Árvore, v.39, p.283-293, 2015. DOI: 10.1590/0100-67622015000200008.

PIRES, P.P.; WENDLING, I.; BRONDANI, G. Ácido indolbutírico e ortotropismo na miniestaquia de Araucaria angustifolia. Revista Árvore, v.37, p.393-399, 2013. DOI: 10.1590/S010067622013000300002 .

PRADO NETO, M. Germinação de sementes e enxertia de jenipapeiro. 2006. 46p. Dissertação (Mestrado) - Universidade Federal da Bahia, Cruz das Almas.

RAKOCEVIC, M.; MEDRADO, M.J.S.; LUCAMBIO, F.; VALDUGA, T.A. Influência do sexo, da sombra e da idade de folhas no sabor do chimarrão. Análise, v.8, p.10, 2006.

REZENDE, A.A. Enraizamento de estacas de candeia (Eremanthus erytropappus (DC.) MacLeish). 2007. 75p. Dissertação (Mestrado) - Universidade Federal de Lavras, Lavras.

RICKLI, H.C.; BONA, C.; WENDLING, I.; KOEHLER, H.S.; ZUFFELLATO-RIBAS, K.C. Origem de brotações epicórmicas e aplicação de ácido indolilbutírico no enraizamento de estacas de Vochysia bifalcata Warm. Ciência Florestal, v.25, p.385-393, 2015. DOI: $10.5902 / 1980509818457$.

ROCHA, M. das G. de B.; ROCHA, D.; CLEMENTE, V.M.; FREITAS, M.V.; GOMES, R.; JESUS, S.V.; CHAVES, R.M.; TORRES, G.A.; XAVIER, A. Propagação vegetativa de espécies arbóreas nativas. In: ROCHA, M. das G. de B. Melhoramento de espécies arbóreas nativas. Belo Horizonte: Instituto Estadual de Florestas, 2002. p.91-108.

SAMPAIO, P. de T.B.; BARBOSA, A.P.; VIEIRA, G.; SPIRONELLO, W.R.; BRUNO, F.M.S. Biomassa da rebrota de copas de pau-rosa (Aniba rosaeodora Ducke) em plantios sob sombra parcial em floresta primária. Acta Amazonica, v.35, p.491-494, 2005. DOI: 10.1590/S0044-59672005000400014.

SANTIN, D.; WENDLING, I.; BENEDETTI, E.L.; BRONDANI, G.E.; REISSMANN, C.B.; MORANDI, D.; ROVEDA, L.F. Poda e anelamento em erva-mate (Ilex paraguariensis) visando a indução de brotações basais. Pesquisa Florestal Brasileira, n.56, p.97-104, 2008.

SANTIN, D.; WENDLING, I.; BENEDETTI, E.L.; MORANDI, D.; DOMINGOS, D.M. Sobrevivência, crescimento e produtividade de plantas de erva-mate produzidas por miniestacas 
juvenis e por sementes. Ciência Florestal, v.25, p.571-579, 2015. DOI: $10.5902 / 1980509819608$.

SASSO, S.A.Z.; CITADIN, I.; DANNER, A.M. Propagação de jabuticabeira por enxertia e alporquia. Revista Brasileira de Fruticultura, v.32, p.571-576, 2010. DOI: 10.1590/S010029452010005000055.

SCALOPPI JUNIOR, E.J. Propagação de espécies de Annonaceae com estacas caulinares. 2007. 92p. Tese (Doutorado) - Universidade Estadual Paulista, Jaboticabal.

SILVA, I.C. Propagação vegetativa de Ocotea puberula Benth e Hook e Ocotea pretiosa Nees pelo método da estaquia. 1984. 109p. Dissertação (Mestrado) - Universidade Federal do Paraná, Curitiba.

SILVA, R.L. da; OLIVEIRA, M.L. de; MONTE, M.A.; XAVIER, A. Propagação clonal de guanandi (Calophyllum brasiliense) por miniestaquia. Agronomía Costarricense, v.34, p.99-104, 2010.

SODRÉ, G.A.; CORÁ, J.E. Substratos para enraizamento de miniestacas de cacaueiro. Agrotrópica, v.19, p.39-42, 2007.

SOUZA, A. das G.C. de; RESENDE, M.D.V. de; SILVA, S.E.L. da; SOUSA, N.R. The cupuaçu genetic improvement program at Embrapa Amazônia Ocidental. Crop Breeding and Applied Biotechnology, v.2, p.471-478, 2002. DOI: 10.12702/1984-7033. v02n03a19.

SOUZA, C.C. Propagação vegetativa de paricá (Schizolobium amazonicum Huber ex. Ducke) e guapuruvu (Schizolobium parahyba (Vell.) Blake) por miniestaquia. 2015. 78p. Tese (Doctor Scientiae) - Universidade Federal de Viçosa, Viçosa.

STUEPP, C.A.; BITENCOURT, J. de; WENDLING, I.; KOEHLER, H.S.; ZUFFELLATO-RIBAS, K.C. Propagação de erva-mate utilizando brotações de anelamento e decepa em matrizes de duas idades. Cerne, v.21, p.519-526, 2015. DOI: $10.1590 / 01047760201521041864$.

STUEPP, C.A.; BITENCOURT, J. de; WENDLING, I.; KOEHLER, H.S.; ZUFFELLATO-RIBAS, K.C. Indução de brotações epicórmicas por meio de anelamento e decepa em erva-mate. Ciência Florestal, v.26, p.1009-1022, 2016a. DOI: 10.5902/1980509824230.

STUEPP, C.A.; BITENCOURT, J. de; WENDLING, I.; KOEHLER, H.S.; ZUFFELLATO-RIBAS, K.C. Métodos de resgate e idades cronológicas de plantas-matrizes no enraizamento de brotações epicórmicas de Ilex paraguariensis. Ciência Florestal, v.27, p.1409-1413, 2017a. DOI: $10.5902 / 1980509830223$.

STUEPP, C.A.; BITENCOURT, J.; WENDLING, I.; KOEHLER, H.S.; ZUFFELLATO-RIBAS, K.C. Age of stock plants, seasons and IBA effect on vegetative propagation of Ilex paraguariensis . Revista Árvore, v.41, e410204, $2017 \mathrm{~b}$. DOI: 10.1590/1806-90882017000200004.

STUEPP, C.A.; WENDLING, I.; KOEHLER, H.S.; ZUFFELLATO-RIBAS, K.C. Quality of clonal plants of Piptocarpha angustifolia in different renewable substrates and seasons of the year. Pesquisa Agropecuária Brasileira, v.51, p.1821-1829, 2016b. DOI: 10.1590/S0100-204X2016001100004.
STUEPP, C.A.; WENDLING, I.; KOEHLER, H.S.; ZUFFELLATO-RIBAS, K.C. Successive mini-cuttings collection in Piptocarpha angustifolia mini-stumps: effects on maturation, adventitious root induction and root vigor. Acta Scientiarum. Agronomy, v.39, p.245-253, 2017c. DOI: 10.4025/actasciagron. v39i2.31059.

STURION, J.A.; STUEPP, C.A.; WENDLING, I. Genetic parameters estimates and visual selection for leaves production in Ilex paraguariensis. Bragantia, v.76, p.492-500, 2017. DOI: 10.1590/1678-4499.2016.419.

TELEGINSKI, F. Propagação vegetativa e germinação de sementes de Campomanesia xanthocarpa Mart. ex O. Berg. 2016. 91p. Dissertação (Mestrado) - Universidade Federal do Paraná, Curitiba.

TINLEY, G.H.; GARNER, R.J. Developments in the propagation of clones of Hevea brasiliensis by cuttings. Nature, v.186, p.407408, 1960. DOI: 10.1038/186407a0.

VENTURIERI, G.A.; MARTEL, J.H.I.; MACHADO, G.M.E. Enxertia do cupuaçuzeiro (Theobroma grandiflorum (Wild ex Spreng) Schum) com uso de gemas e garfos com e sem toalete. Acta Amazonica, v.16/17, p.27-40, 1986/1987. DOI: 10.1590/180943921986161040.

WENDLING, I. Enxertia e florescimento precoce em Araucaria angustifolia. Colombo: Embrapa Florestas, 2011. 7p. (Embrapa Florestas. Comunicado técnico, 272).

WENDLING, I. Tecnologia de enxertia de Araucaria angustifolia para produção precoce de pinhões, complantas de porte reduzido. Colombo: Embrapa Florestas, 2015. 7p. (Embrapa Florestas. Comunicado técnico, 351).

WENDLING, I.; BRONDANI, G.E. Vegetative rescue and cuttings propagation of Araucaria angustifolia (Bertol.) Kuntze. Revista Árvore, v.39, p.93-104, 2015. DOI: 10.1590/010067622015000100009.

WENDLING, I.; BRONDANI, G.E.; BIASSIO, A. de; DUTRA, L.F. Vegetative propagation of adult Ilex paraguariensis trees through epicormic shoots. Acta Scientiarum. Agronomy, v.35, p.117-125, 2013. DOI: 10.4025/actasciagron.v35i1.15958.

WENDLING, I.; DUTRA, L.F.; GROSSI, F. Produção e sobrevivência de miniestacas e minicepas de erva-mate cultivadas em sistema semi-hidropônico. Pesquisa Agropecuária Brasileira, v.42, p.289-292, 2007. DOI: 10.1590/S0100204X2007000200019.

WENDLING, I.; DUTRA, L.F.; HOFFMANN, H.A.; BETTIO, G.; HANSEL, F. Indução de brotações epicórmicas ortotrópicas para a propagação vegetativa de árvores adultas de Araucaria angustifolia. Agronomía Costarricense, v.33, p.309-319, 2009a.

WENDLING, I.; FERRARI, M.P.; DUTRA, L.F. Produção de mudas de cortiçeira-do-mato por miniestaquia a partir de propágulos juvenis. Colombo: Embrapa Florestas, 2005. 5p. (Embrapa Florestas. Comunicado técnico, 130).

WENDLING, I.; LAVORANTI, O.J.; RESENDE, M.D.V.; HORRMAN, H.A. Seleção de matrizes e tipo de propágulo na enxertia de substituição de copa em Ilex paraguariensis. 
Revista Árvore, v.33, p.811-819, 2009b. DOI: 10.1590/S010067622009000500004 .

WENDLING, I.; STUEPP, C.A.; SANTIN, D.; ZUFFELLATORIBAS, K.C. Clonal forestry of Araucaria angustifolia: plants produced by grafting and cuttings can be used for wood production. Revista Árvore, v 41, e410117, $2017 \mathrm{a}$.

WENDLING, I.; STUEPP, C.A.; ZUFFELLATO-RIBAS, K.C. Araucaria angustifolia grafting: techniques, environments and origin of propagation material. Bosque, v.37, p.285-293, 2016a. DOI: $10.4067 /$ S0717-92002016000200007.

WENDLING, I.; STUEPP, C.A.; ZUFFELLATO-RIBAS, K.C. Araucaria clonal forestry: types of cuttings and mother tree sex in field survival and growth. Cerne, v.22, p.19-26, 2016b. DOI: 10.1590/01047760201622012105.

WENDLING, I.; STUEPP, C.A.; ZUFFELLATO-RIBAS, K.C. Rooting of Araucaria angustifolia: types of cuttings and stock plants sex. Revista Árvore, v.40, p.1013-1021, 2016c. DOI: 10.1590/0100-67622016000600006.

WENDLING, I.; TRUEMAN, S.J.; XAVIER, A. Maturation and related aspects in clonal forestry - Part I: concepts, regulation and consequences of phase change. New Forests, v.45, p.449-471, 2014a. DOI: 10.1007/s11056-014-9421-0.

WENDLING, I.; TRUEMAN, S.J.; XAVIER, A. Maturation and related aspects in clonal forestry - Part II: reinvigoration, rejuvenation and juvenility maintenance. New Forests, v.45, p.473-486, 2014b. DOI: 10.1007/s11056-014-9415-y.
WENDLING, I.; XAVIER, A. Gradiente de maturação e rejuvenescimento aplicado em espécies florestais. Floresta e Ambiente, v.8, p.187-194, 2001.

WENDLING, I.; ZANETTE, F.; RICKLI-HORSTI, H.C.; CONSTANTINO, V. Produção de mudas de araucária por enxertia. In: WENDLING, I.; ZANETTE, F. (Ed.). Araucária: particularidades, propagação e manejo de plantios. Brasília: Embrapa, 2017b. p.107-144.

XAVIER, A.; SANTOS, G.A. dos; OLIVEIRA, M.L. de. Enraizamento de miniestaca caulinar e foliar na propagação vegetativa de cedro-rosa (Cedrela fissilis Vell.). Revista Árvore, v.27, p.351-356, 2003a. DOI: 10.1590/S0100-67622003000300011.

XAVIER, A.; SANTOS, G.A. dos; OLIVEIRA, M.L. de. Propagação vegetativa de cedro-rosa por miniestaquia. Revista Árvore, v.27, p.139-143, 2003b. DOI: 10.1590/S010067622003000200003.

XAVIER, A.; SILVA, R.L. da. Evolução da silvicultura clonal de Eucalyptus no Brasil. Agronomía Costarricense, v.34, p.93-98, 2010.

XAVIER, A.; WENDLING, I. SILVA, R.L. da. Silvicultura clonal: princípios e técnicas. 2.ed. rev. e ampl. Viçosa: Ed. da UFV, 2013. 278p.

ZANETTE, F.; OLIVEIRA, L. da S.; BIASI, L.A. Grafting of Araucaria angustifolia (BERTOL.) kuntze through the four seasons of the year. Revista Brasileira de Fruticultura, v.33, p.1364-1370, 2011. DOI: 10.1590/S0100-29452011000400040.

$\overline{\text { Received on November 21, } 2016 \text { and accepted on November 27, } 2017}$ 